\title{
Origins of Construction and Demolition Waste Generation in the Sri Lankan Construction Industry
}

\author{
K.L.A.K.T. Liyanage*, K.G.A.S.Waidyasekara, B.H.Mallawaarachchi and T.P.W.S.I. \\ Pandithawatta
}

University of Moratuwa, Sri Lanaka

\begin{abstract}
C\&D waste management is an area where attention needs to be paid for as the construction industry is considered to be one of the key solid waste generators. Mainly, C\&D waste get generated through the new construction, renovation of buildings, and through the demolition of buildings and structures. Hence, it is necessary to manage the C\&D waste. In order to manage the C\&D waste, it is necessary to identify the types and origins of waste. Thus, the aim of the paper is to identify the types of C\&D waste and their origins of generation. This paper critically reviews secondary data and findings of eight case studies under the qualitative approach. Through the case study findings, it was evident that plywood, concrete, cement, steel offcuts, blocks bricks, sand, soil, wood, polythene and food waste as the main types of C\&D waste in Sri Lankan construction sites. Further, design changes, transport, human mistakes, quality of works, client changes and mismatches in required materials are identified as the key origins for C\&D waste generation in Sri Lankan construction sites. Therefore, to achieve the aim of the paper, types of $C \& D$ waste materials and origins of $C \& D$ waste generation were identified.
\end{abstract}

Keywords: Construction and Demolition (C\&D) waste, Waste Materials, Waste Management, Sri Lankan Construction Industry

\section{Introduction}

Construction industry being one of the largest industries, make a considerable contribution to the Gross National Product (Elgizawy et al.2016; Sapuay, 2016). Further, Elgizawy et al. (2016) have stated that as bigger portion of solid waste generation is through the construction industry attention is being paid to C\&D waste management (Banihashemi et al., 2018; Hao et al., 2007). Moreover, out of the generated C\&D waste, nearly 10-30\% are dumped in landfills causing number of environmental, social and economical problems (Agamuthu 2008; Wang et al., 2010).

According to Coelho and Brito (2012), due to the generation of C\&D waste, ecological damages, land depletion, scarcities in land resources and pollutions take place. Furthermore, unsustainability in the construction industry is largely due to the massive C\&D waste generation (Elgizawy et al., 2016).Thus, Lingard et al., (2000) have said that through proper $C \& D$ waste management adveres impacts of $C \& D$ waste can be overcomed.

In order to overcome the adverse impacts and to have proper $C \& D$ waste management, strategies need to be implemented (Magalhaes et al., 2017). Further, policies and regulations needs to be implemented by the government to manage $C \& D$ waste (Oluwole \& Olaniran, 2013). In order to manage the $C \& D$ waste, it is necessary to identify the types and origins of waste generation. Hence, this paper focuses on the C\&D waste types and their origins of generation in the Sri Lankan construction industry.

\section{Literature Review}

\section{Definitions of $C \& D$ waste}

When considering about the $C \& D$ waste, different authors have given different definitions for the $C \& D$ waste. In simple, all types of waste generated as a result of construction activities are identified as C\&D waste (Hsiao et al., 2002). Further, Yuan and Shen (2011) have defined Solid waste that is generated due to construction 
activities as C\&D waste. Moreover, many authors have defined C\&D waste that is generated in construction, repair of buildings, maintenance and demolition (Christensen \& Andersen, 2011; Ghosh \& Ghosh, 2016; Kofoworola \& Gheewala, 2008).

\section{Origins of C\&D Waste}

$C \& D$ waste get generated due to the errors in design, lack of knowledge in material handling, poor material planning decisions and due to changes in building design (Yeheyis, et al., 2013). Furthermore, when the required data for the selection of construction method, inadequate knowledge in sequential order of construction activities, C\&D waste get generated. Moreover, procurement issues, transportation issues, material storage issues, handling of material issues, issues in site operation, residual issues, weather issues and vandalism issues have resulted in the generation of C\&D waste (Begum et al., 2006; Gavilan\& Bernold, 1994; Osmani, et al.,2008).

Changes in design during the construction, incomplete documents to start construction, poor quality assurance and quality control in specifications have resulted in the generation of waste (Bossink \& Brouwers, 1996). Further, lack of awareness in environmental protection and selection of structures, inadequate management skills, and inadequate training on waste management are the reasons for the generation of C\&D waste (Wang et al., 2008). Moreover, Magalhaes et al. (2017) explained that construction planning and designing decisions also lead to the C\&D waste generation.

\section{Composition of $C \& D$ waste}

C\&D waste comprises of ceramics, concrete, electrical wiring ,bricks, tiles, wood, tar and tarred products, glass, hazardous components plastic, asphalt, metals soil and dredged soil, mixed C\&D, insulation materials, and gypsum based materials ( Ghosh \& Ghosh, 2016). Further, Hsiao et al. (2002) have stated that, C\&D waste consists of sand, stone, pottery and porcelain, dirt brick, glass, tile, concrete, remaining mud, asphalt, concrete, timber, plastic, bamboo, paper, and metal. Moreover, Wang et al. (2008) have stated that out of the generated C\&D waste, $95 \%$ can be recycled while remaining 5\% is unrecyclable. Similarly, Shen et al. (2004) have said that C\&D waste comprise of building debris, earth, steel, timber concrete, rubble, and mixed site clearance materials. In addition to that, soil, gravel, pieces of concrete, lime-cast, dressed stone, porcelain, concrete, wood, metal ferrous (Steel), metal Non ferrous (Copper, Aluminum), masonry (bricks and mortar), plastic (PVC pipes, plastic films for packaging, wall coverings), glass, ceramic tiles, insulation material (mineral wool insulation, Styrofoam), drywall or gypsum board, filling material (gravel, sand and soil), paper and cardboard, marble and granite (Elgizawy et al., 2016; Shen et al.,2004).

\section{C\&D Waste Management in Sri Lankan Construction Industry}

In the Sri Lankan context, no specific regulation is available for the management of C\&D waste and C\&D waste is classified under solid waste (Karunasena, et al., 2012). Further, Jayawardane (1992) has stated that, in the Sri Lankan construction industry, wastages of resources like plant, labour, and space are beyond reasonable limits. Moreover, the author has identified that the waste generated in the construction sites of Sri Lanka as a considerable problem to be addressed. In addition to that, according to Kulatunga et al. (2006), wastage of materials in Sri Lankan construction sites are beyond the acceptable limit (as cited by Jayawardena, 1994). As per Jayawardane and Gunawardena (1998) in the current context, operations of the construction industry are regulated by the Institute for Construction Training and Development (ICTAD). In Sri Lanka, the value added of construction activities grew by 3.1 percent in 2017 and a number of large scale residential and mixed development projects and infrastructure projects have contributed to the growth in the construction activities (Central Bank of Sri Lanka, 2017). 
In carrying out construction activities, materials are the largest input into the construction activities where it leads to the generation of waste (Rameezdeen, et al., 2004). Further, Kulatunga et al. (2006) have stated that, there is a significant impact on the cost of waste in the Sri Lankan construction industry. In addition to that, Karunasena et al. (2012) have stated that, although landfilling is considered to be the least preferred option in waste process, in Sri Lankan context landfilling has become the first option to manage C\&D waste. Table 1 shows the C\&D material wastage in Sri Lanka

Table 1.: Material wastage in Sri Lanka

\begin{tabular}{lc}
\hline Material & Material Waste as a Percentage \\
\hline Sand & 25 \\
Lime & 20 \\
\hline Cement & 14 \\
\hline Bricks & 14 \\
\hline Ceramic Tiles & 10 \\
\hline Timber (Formwork) & 10 \\
\hline Rubble & 7 \\
\hline Steel (Reinforcement) & 7 \\
\hline Cement blocks & 6 \\
\hline Paint & 5 \\
\hline Asbestos sheets & 3 \\
\hline
\end{tabular}

Source : Rameezdeen et al. (2004)

According to Rameezdeen et al. (2004), the main causes for C\&D waste in Sri Lanka are, cutting waste which takes place due to cutting of materials in different sizes and uneconomical shapes and management waste which take place as a result of incorrect decision making and lack of supervision. Furthermore, as a result of the Tsunami disaster which took place in the year 2004, 450, 000 tonnes of building waste were generated in Sri Lanka and a post Tsunami programe called Construction Waste Management (COWAM) project was initiated to manage C\&D waste in Sri Lanka (Karunasena, et al. 2009,2012). Although COWAM project was initiated to manage C\&D waste, due to the lack of technology, funds, unfamiliarity and unawareness of recycled building materials, building waste recycling projects have not been implemented in Sri Lanka (Karunasena, et al., 2009) . Therefore, considering all the above discussed facts, it is clear that C\&D waste management in the Sri Lankan context is still in a primary stage.

\section{Methodology}

Journal articles, books, conference proceedings related to $C \& D$ waste types, origins were reffered to collect data. Following the literature review, for the data collection case study strategy under the qualitative approach was used. Under the qualitative approach, eight (08) case studies were carried out and details of the cases are shown in Table 2. Moreover, semi structured interviews were carried out with twenty seven (27) respondents and respondents details are shown in Table 3 . Selected cases were under the building construction CS2 grade in Construction Industry Development Authority (CIDA).

Table 2 : Case Study Details

\begin{tabular}{llllllllll}
\hline Criteria & & Case A & Case B & Case C & Case D & Case E & Case F & Case G & Case H \\
\hline $\begin{array}{l}\text { Cost of the project } \\
\text { (Billion) }\end{array}$ & 4 & 0.28 & 1.2 & 0.76 & 1.89 & 40 & 0.4 & 3.08 \\
\hline $\begin{array}{l}\text { Duration of the project } \\
\text { (Months) }\end{array}$ & 36 & 18 & 18 & 18 & 24 & 26 & 18 & 20 \\
\hline
\end{tabular}


Table 3 : Profile of the interviewees

\begin{tabular}{|c|c|c|c|}
\hline Profession & Code & Interviewee from each case & Experience \\
\hline \multirow{2}{*}{ Project Manager } & PM & PM-C & 26years \\
\hline & & PM-E & 18years \\
\hline \multirow[t]{4}{*}{ Planning Engineer } & $\mathrm{PE}$ & PE-A & 7 years \\
\hline & & PE-B & 5 years \\
\hline & & PE-F & 13 years \\
\hline & & PE-H & $41 / 2$ years \\
\hline \multirow[t]{5}{*}{ Site Engineer } & SE & SE-C & 4 years \\
\hline & & SE-D & 6 years \\
\hline & & SE-F & 3 years \\
\hline & & SE-G & $51 / 2$ years \\
\hline & & SE-H & $31 / 2$ years \\
\hline \multirow[t]{8}{*}{ Safety Officer } & $\mathrm{SO}$ & SO-A & 7 years \\
\hline & & SO-B & 5 years \\
\hline & & $\mathrm{SO}-\mathrm{C}$ & 8 years \\
\hline & & SO-D & $4 \frac{1}{2}$ years \\
\hline & & SO-E & 4 years \\
\hline & & $\mathrm{SO}-\mathrm{F}$ & 12 years \\
\hline & & SO-G & $21 / 2$ years \\
\hline & & $\mathrm{SO}-\mathrm{H}$ & 8 years \\
\hline Mason & MA & MA-E & $11 / 2$ years \\
\hline Store Keeper & SK & SK-B & 1 year \\
\hline \multirow[t]{6}{*}{ Labourer } & LA & LA-A & 10 months \\
\hline & & LA-C & 1 year \\
\hline & & LA-D & $1 \frac{1}{2}$ years \\
\hline & & LA-F & $11 / 2$ years \\
\hline & & LA-G & 8 months \\
\hline & & LA-F & 1 year \\
\hline
\end{tabular}

\section{Results and Discussion}

\section{Types of C\&D Waste Materials}

In the construction industry, $C \& D$ waste management is a critical issue that needs to be addressed. Following Table 4 shows the C\&D waste composition according to the case study findings.

Table 4: Waste Types and their Source of Generation

\begin{tabular}{|c|c|c|c|c|c|c|c|c|}
\hline Type of Waste & Case A & Case B & Case $\mathrm{C}$ & Case D & Case E & Case F & Case $\mathrm{G}$ & Case H \\
\hline Plywood & $\sqrt{ }$ & $\sqrt{ }$ & $\sqrt{ }$ & $\sqrt{ }$ & $\sqrt{ }$ & $\sqrt{ }$ & $\sqrt{ }$ & $\sqrt{ }$ \\
\hline Concrete & $\sqrt{ }$ & $\sqrt{ }$ & $\sqrt{ }$ & $\sqrt{ }$ & $\sqrt{ }$ & $\sqrt{ }$ & $\sqrt{ }$ & $\sqrt{ }$ \\
\hline Cement & $\sqrt{ }$ & $\sqrt{ }$ & $\sqrt{ }$ & $\sqrt{ }$ & $\sqrt{ }$ & $\sqrt{ }$ & $\sqrt{ }$ & $\sqrt{ }$ \\
\hline Steel/ Offcuts & $\sqrt{ }$ & $\sqrt{ }$ & $\sqrt{ }$ & $\sqrt{ }$ & $\sqrt{ }$ & $\sqrt{ }$ & $\sqrt{ }$ & $\sqrt{ }$ \\
\hline Blocks & $\sqrt{ }$ & & & & $\sqrt{ }$ & $\sqrt{ }$ & & $\sqrt{ }$ \\
\hline Bricks & & $\sqrt{ }$ & $\sqrt{ }$ & $\sqrt{ }$ & & & $\sqrt{ }$ & $\sqrt{ }$ \\
\hline Sand & $\sqrt{ }$ & & & $\sqrt{ }$ & $\sqrt{ }$ & & $\sqrt{ }$ & \\
\hline Soil & & $\sqrt{ }$ & $\sqrt{ }$ & & & & & $\sqrt{ }$ \\
\hline Wood waste & $\sqrt{ }$ & $\sqrt{ }$ & $\sqrt{ }$ & & $\sqrt{ }$ & $\sqrt{ }$ & $\sqrt{ }$ & $\sqrt{ }$ \\
\hline Polythene & $\sqrt{ }$ & $\sqrt{ }$ & $\sqrt{ }$ & & & $\sqrt{ }$ & $\sqrt{ }$ & \\
\hline Cardboard & $\sqrt{ }$ & & & & & $\sqrt{ }$ & & \\
\hline
\end{tabular}




\begin{tabular}{|c|c|c|c|c|}
\hline Plastic/ PVC & $\sqrt{ }$ & & $\sqrt{ }$ & $\sqrt{ }$ \\
\hline Paper & 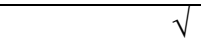 & & & \\
\hline Aggregate & $\sqrt{ }$ & & & \\
\hline Tile offcuts & & $\sqrt{ }$ & & \\
\hline Concrete nails & & & $\sqrt{ }$ & \\
\hline MEP waste & $\sqrt{ }$ & & & \\
\hline Wire nails & & & $\sqrt{ }$ & \\
\hline Welding rods & & & $\sqrt{ }$ & \\
\hline Tool wastage & & & $\sqrt{ }$ & \\
\hline Food waste & $\sqrt{ } \quad \sqrt{ }$ & $\sqrt{ }$ & $\sqrt{ }$ & $\sqrt{ }$ \\
\hline
\end{tabular}

When analysing the C\&D waste in the construction industry, as per the case study findings, there are $C \& D$ waste types like plywood, concrete, steel offcuts, blocks, bricks, sand, aggregate, cement, soil, MEP waste, wood waste $(2 \times 2,2 \times 4)$, polythene, cardboard, plastic, PVC, paper, tile offcuts, concrete nails, wire nails, welding rods, tool wastage and food waste. In the study, almost all the respondents have identified concrete, plywood, cement, and steel offcuts as the main type of C\&D waste in their sites. Moreover, two (02) to three (03) respondent from each case have identified, cardboard, plastic, PVC, paper, tile offcuts, concrete nails, wire nails, welding rods in their $\mathrm{C} \& \mathrm{D}$ waste composition. In addition to that, respondents $\mathrm{PM}-\mathrm{C}$ of case $\mathrm{C}$ stated that, in their site, during the foundation stage, there were unusable weak soil and in piling stage, there were bentonite contaminated soil. So these soil types are unable to use for the backfillings in the site and due to that reason they are removed from the site as waste.

\section{Waste Origins}

C\&D waste can get generated due to number of reasons. Table 5 shows the origins of waste generation.

Table 5 : Waste Origins

\begin{tabular}{|c|c|c|c|c|c|c|c|c|}
\hline Origins of Waste & $\begin{array}{c}\text { Case } \\
\text { A }\end{array}$ & Case B & Case $\mathrm{C}$ & Case D & Case E & Case $\mathrm{F}$ & Case $\mathrm{G}$ & Case $\mathrm{H}$ \\
\hline Design changes & $\sqrt{ }$ & $\sqrt{ }$ & $\sqrt{ }$ & $\sqrt{ }$ & $\sqrt{ }$ & $\sqrt{ }$ & $\sqrt{ }$ & $\sqrt{ }$ \\
\hline Transport & $\sqrt{ }$ & $\sqrt{ }$ & $\sqrt{ }$ & $\sqrt{ }$ & $\sqrt{ }$ & $\sqrt{ }$ & $\sqrt{ }$ & $\sqrt{ }$ \\
\hline Human Mistakes & $\sqrt{ }$ & $\sqrt{ }$ & $\sqrt{ }$ & $\sqrt{ }$ & & $\sqrt{ }$ & $\sqrt{ }$ & $\sqrt{ }$ \\
\hline Quality of works & $\sqrt{ }$ & & & $\sqrt{ }$ & $\sqrt{ }$ & $\sqrt{ }$ & $\sqrt{ }$ & $\sqrt{ }$ \\
\hline Client Changes & $\sqrt{ }$ & & $\sqrt{ }$ & & & $\sqrt{ }$ & & $\sqrt{ }$ \\
\hline $\begin{array}{l}\text { Mismatches in } \\
\text { required materials }\end{array}$ & & $\sqrt{ }$ & $\sqrt{ }$ & & $\sqrt{ }$ & $\sqrt{ }$ & $\sqrt{ }$ & $\sqrt{ }$ \\
\hline Labour skills & $\sqrt{ }$ & & & & $\sqrt{ }$ & $\sqrt{ }$ & & $\sqrt{ }$ \\
\hline Weather Condition & & $\sqrt{ }$ & & & $\sqrt{ }$ & & & \\
\hline End of product life & & $\sqrt{ }$ & & & & & $\sqrt{ }$ & \\
\hline Negligence & & & & & $\sqrt{ }$ & $\sqrt{ }$ & $\sqrt{ }$ & \\
\hline Material handling & & & & & $\sqrt{ }$ & $\sqrt{ }$ & & $\sqrt{ }$ \\
\hline $\begin{array}{l}\text { Changes by Architect } \\
\text { and Engineer }\end{array}$ & & & $\sqrt{ }$ & & & & & \\
\hline Poor Supervision & & & & & & & $\sqrt{ }$ & \\
\hline
\end{tabular}

$C \& D$ waste in the constructon industry gets generated due to a number of reasons. As per the case study findings, main reasons to generate C\&D waste are design changes and transportation. In addition to that, there 
are other reasons which lead to C\&D waste generation and they are, client changes, human mistakes, quality of work, labour skills, weather condition, end of product life cycle, mismatch in required materials for the construction activities, changes carried out by the engineer and architect, negligence, material handling and poor supervision.

Respondents PM-C from the case C stated that, waste get generated due to client, architect, and structural engineer changes. Respondent, further stated that,

"in the stage of ducts establishment, there will be chances of ducts start to crossover each other. In such scenario, there will be difficulties in taking the minimum height between the floors. So in order to overcome the issue, sometimes beam needs to be drilled or needs to be break. So it creates waste".

In addition to that, he also explained, "tile and ceramic wastages can occur due to transport". Furthermore, respondent SE-D stated that, when the bricks are brought into the basement of the site, they need to be transported to the upper flows of the site. For the transport of bricks, hand transport method is used. In the process of brick transportation, at first bricks are unloaded to the site basement. Then from the basement, bricks are put into the hoist. From the hoist, bricks are transported to the upper floors. So in this instance of brick transportation, brick is nearly transported 4 times before they are being used for construction. Hence, brick waste get generated during the transportation process. Moreover, respondent SE-D also stated that, sand waste get generated in the process of transportation from the basement of the site to the upper stories of the building.

Respondent SE-C and respondent PM-E explained that, waste get generated due to the mismatch in materials required and materials available. They elaborated this scenario through the example of steel bar. For a specific work, required steel bar size is $10 \mathrm{~m}$ and the available steel bar sizes are $6 \mathrm{~m}$ and $12 \mathrm{~m}$. So it ultimately generates a steel offcut of $2 \mathrm{~m}$ which is a waste from that specific activity. Furthermore, respondent PM-E stated that,

"if we specify the supplier that, for a specific work, required bar size is $7.1 \mathrm{~m}$ and asked them to provide the quantities, then there will be no any wastage. But, to do a procurement as such, at least 20 tons of steel bars from the same size need to be ordered".

As per the findings, weather condition is another reason for waste generation. Respondent SO-E of case E stated that, "sand wastages and steel corrosion take place due to weather conditions". In the site, sand is collected in an open yard, and due to rain, sand can get washed away by creating a waste. Further, respondent SO-E also explained that, due to weather conditions, steel get rusted and sometimes it creates waste. Most of the time, such steels are reused after doing the wire brushing.

Respondent SO-E also stated that, C\&D waste get generated from the material handling methods. When there is a slab construction, measurements and quantities are taken before hand. There may be changes in the quantities and measurements. That means, there may be excess materials. In such instances, excess can be used for fillings in the floors or to prepare drains. Such activities need to be preplanned in the material handling stage and in material purchasing stage. Similarly, SO-E also said that, waste like plywood get generated as a result of the end of the product life cycle. Normally in the site plywoods are used for 4-5 times and when they get mixed with water, layers of the plywood get loose and it leads to wastages.

Respondent PE-F said that waste get generated due to human mistakes and due to the negligence. When there are calculation errors in the stage of procurement, there are wastages. For example, where concrete is purchased, due to the errors in volume calculation, there can be excess quantity of concrete. Respondent further elaborated that,

"if such thing take place in the site, it is being sent back to the main batching plant and they are being reused. In this site, for the construction, high grading concrete like grade 50 to 70 are being used. 
These concrete can be degraded by mixing with sand. So it can be used for domestic construction, as 20 grade concrete is being used for domestic construction".

\section{Conclusions}

Construction industry being one of the key contributors in solid waste generation, C\&D waste needs to be managed in a systematic way. Thus, attention is paid to manage C\&D waste to reduce adverse impacts such as environmental pollution, issues in social and economic aspects. To eliminate the C\&D waste, it is necessary to identify the types and origins of C\&D waste generation. Hence, this paper has discussed types and origins of C\&D waste. The study revealed that, main type of C\&D waste is plywood, concrete, cement and steel/ offcuts while design changes, transportation, human mistakes and quality of works as the main origins of waste generation. Therefore, the aim of the paper which was to identify the C\&D waste types and its origins of waste generation were achieved. Further, the generated waste is transported away from the site through waste collectors and recyclers and finally the waste is dumped into landfills. Thus, elimination of C\&D waste through a concept like zero waste is a precise solution to overcome from the C\&D waste issue.

\section{Acknowledgement}

The authors wish to acknowledge the support received from the Senate Research Committee of University of Moratuwa under the Grant SRC/LT/2018/16.

\section{References}

Agamuthu, P., 2008. Challenges in sustainable management of construction and demolition waste. Waste Management \& Research, Volume 26, pp. 491-492.

Banihashemi, S., Tabadkani, A. and Hosseini, M. R., 2018. Integration of parametric design into modular coordination: A construction waste reduction workflow. Automation in Construction, Volume 88, pp. 1-12.

Begum, R., Siwar, C., Pereira, . J. \& Jaafa, A., 2006. A benefit-cost analysis on the economic feasibility of construction waste minimization: The case of Malaysia. Resource Conservation and Recycling, Volume 48, pp. $86-98$

Bossink, B.A.G. \& Brouwers, H.J.H., 1996. Construction Waste: Quantification and Source Evaluation. Journal of Construction Engineering and Management, pp.55-60.

Central Bank of Sri Lanka, 2017. Annual Report 2017, Colombo: Central Bank of Sri lanka.

Christensen, T. H. \& Andersen, L., 2011. Construction and Demolition Waste. In: T. H. Christensen, ed. Solid Waste Technology \& Management. s.1.:Blackwell Publishing Ltd, pp. 104-109.

Coelho, A. and Brito, J. d., (2012). Influence of construction and demolition waste management on the environmental impact of buildings. Waste Management, Volume 32, p. 532-541.

Ekanayake, L. \& Ofori , G., 2004. Building waste assessment score : design-based tool. Build Environment, 39(7), pp. 851-861.

Elgizawy, S., Haggar, S., \& Nassar, K. (2016). Slum development using zero waste concepts: construction waste case study. International Conference on Sustainable Design, Engineering and Construction, 145, pp. 1306 - 1313

Gavilan, R. \& Bernold, L., 1994. Source evaluation of solid waste in building construction. Journal of construction engineering and management, 120(3), pp. 536-552.

Ghosh, S. K. \& Ghosh, S. K., 2016. Construction and Demolition Waste. In: Sustainable Solid Waste Management. New York: ASCE, pp. 511-547.

Hao, J., Hills , M. and Huang, T., 2007. A simulation model using system dynamic method for construction and demolition waste management in Hong Kong. Construction Innovation, 7(1), pp. 7-21. 
Hsiao , T., Huang, Y., Yu , Y. and Wernick, I., 2002. Modeling materials flow of waste concrete from construction and demolition wastes in Taiwan. Resources Policy, Volume 28, pp. 39-47.

Jayawardane , A. \& Gunawardena, N., 1998. Construction workers in developing countries: a case study of Sri Lanka. Construction Management and Economics, Volume 16, pp. 521-530.

Jayawardane, A., 1992. Wastage on building construction sites- what the Sri Lankan contractors say. pp. 1-14.

Karunasena, G., Amaratunga, D. and Haigh, R., 2012. Post disaster construction \& demolition debris management : A Sri Lanka case study. Journal of Civil Engineering and Management, 18(4), pp. 457-468.

Karunasena, G., Amaratunga , D., Haigh, R. and Lill, I., 2009. Post disaster waste management strategies in developing countries: Case of Sri Lanka. International Journal of Strategic Property Management, 13(2), pp. 171-190.

Kofoworola, O., and Gheewala, S. (2009). Estimation of construction waste generation and management in Thailand. Waste Management, 29, 731-738. doi:10.1016/j.wasman.2008.07.004

Kulatunga, U., Amaratunga, D., Haigh, R. and Rameezdeen, R., 2006. Attitudes and perceptions of construction workforce on construction waste in Sri Lanka. Management of Environmental Quality An International Journal, $17(1)$, pp. 57-72.

Lingard, H., Graham, P. and Smithers, . G., (2000). Employee perceptions of the solid waste management system operating in a large Australian contracting organization: implications for company policy implementation. Construction Management and Economics, Volume 18, p. 383-393.

Magalhaes, R. F. d., Danilevicz, A. d. M. F. and Saurin, T. A., (2017). Reducing construction waste: A study of urban infrastructure projects. Waste Management, pp. 1-13.

Oluwole Akadiri, P. and Olaniran Fadiya, O., 2013. Empirical analysis of the determinants of environmentally sustainable practices in the UK construction industry. Construction Innovation, 13(4), pp.352373.doi/10.1108/CI-05-2012-0025.

Osmani , M., Glass, J., and Price, A. (2008). Architects' perspectives on construction waste reduction by design. Waste Management, 28, 1147-1158. doi:10.1016/j.wasman.2007.05.01

Rameezdeen, R., Kulatunga, U. \& Amaratunga, D., 2004. Quantification of construction material waste in Sri Lankan sites. Proceedings: International Built and Human Environment Research Week, pp. 1-9.

Sapuay, S. (2016). Construction Waste - Potentials and Constraints. Procedia Environmental Sciences, 35,714 -722 .

Shen, L., Tam, V., Tam, C. \& Drew, D., 2004. Mapping approach for examining waste management on construction sites. Journal of Construction Engineering and Management, 130(4), pp. 472-481.

Wang, J., Yuan, H., Kang, X., and Lu, W. 2010. Critical success factors for on-site sorting of construction waste: A china study. Resources, Conservation and Recycling, 54, 931-936. doi:10.1016/j.resconrec.2010.01.012

Wang, J.-Y., Kang, X.-P., and Tam, V.-Y. 2008. An investigation of construction wastes: an empirical study in Shenzhen. Journal of Engineering, Design and Technology, 6(3), 227-236. doi: 10.1108/17260530810918252

Yeheyis, M. et al., (2013). An overview of construction and demolition waste management in Canada: a lifecycle analysis approach to sustainability. Clean Technologies and Environmental Policy, Volume 15, pp. 8191.

Yuan , H. \& Shen, L., 2011. Trend of the research on construction and demolition waste management. Waste Management, Volume 31, pp. 670-679. 